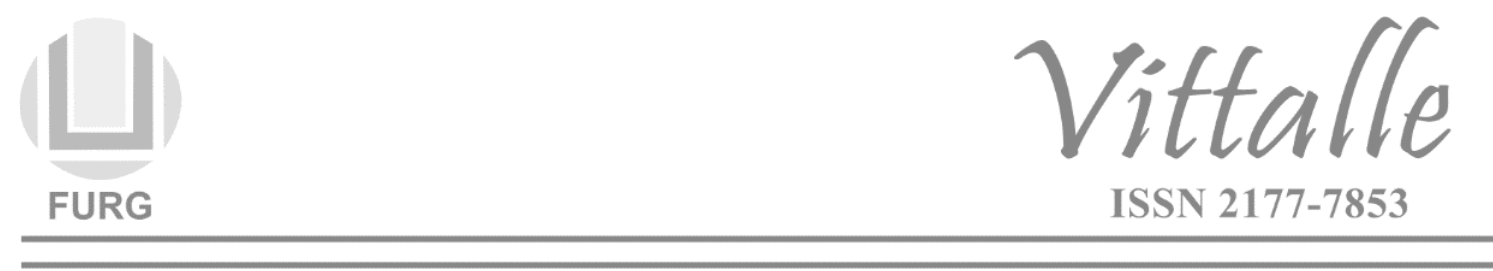

\title{
Paracentese abdominal
}

\author{
Karine Cristina Ghiggi ${ }^{*}$, Hugo Cataud Pacheco Pereira, Daniel Fagundes Audino
}

Faculdade de Medicina, Universidade Federal do Rio Grande, Rio Grande, RS, Brasil

\begin{abstract}
Palavras-chave:
Ascite; Paracentese;

Competência Clínica;

Ensino; Medicina.
\end{abstract}

Keywords:

Ascites; Paracentesis;

Clinical Competence;

Teaching; Medicine.

\begin{abstract}
RESUMO
Paracentese abdominal é um procedimento realizado para obter uma pequena amostra ou drenar líquido ascítico para fins diagnóstico ou terapêutico; é o método mais rápido e econômico para o diagnóstico etiológico de ascite. A causa mais comum de ascite é a cirrose; embora o mecanismo exato do desenvolvimento da ascite não seja completamente compreendido, a maioria das teorias sugere a hipertensão portal como a principal contribuinte; outras causas comuns incluem malignidade e insuficiência cardíaca. A paracentese terapêutica refere-se à retirada de cinco litros ou mais de fluidos para reduzir a pressão intra-abdominal, aliviar a dispneia associada e a dor abdominal. É um procedimento simples à beira do leito que pode reduzir a morbidade em pacientes com doença hepática terminal. Neste capítulo, apresentamos a técnica da paracentese e as particularidades que envolvem a análise do líquido ascítico.
\end{abstract}

Paracentesis

\begin{abstract}
Abdominal paracentesis is a procedure performed to obtain a small sample of or drain ascitic fluid for both diagnostic or therapeutic purposes; is the most rapid and cost-effective method of diagnosing the cause of ascites. The most common cause of ascites is cirrhosis; although the exact mechanism of ascites development is not completely understood, most theories suggest portal hypertension as the main contributor; other common causes include malignancy and heart failure. Therapeutic paracentesis refers to the removal of five liters or more of fluid to reduce intra-abdominal pressure, relieve the associated dyspnea and abdominal pain. It is a simple bedside procedure that can reduce morbidity in patients with end-stage liver disease. In this chapter, we describe the technique of paracentesis and the peculiarities that involve the analysis of ascitic fluid.
\end{abstract}

\section{Introdução}

Paracentese abdominal é um procedimento diagnóstico e/ou terapêutico que consiste em puncionar um cateter no abdome, comumente no quadrante inferior esquerdo (QIE), até a cavidade peritoneal (1). O procedimento é usado na avaliação de várias problemas abdominais, em especial no paciente com ascite cuja doença torna necessário conhecer a composição do líquido acumulado (p. ex., coleta de determinada quantidade de líquido para análise laboratorial) ou, também, no paciente com desconforto respiratório (p. ex., drenagem de grandes volumes a fim de proporcionar uma descompressão imediata de ascite sob tensão) $(1,2)$. A paracentese é um procedimento simples, relativamente seguro, que pode ser executado por qualquer profissional habilitado, seja ele especialista ou não e, em casos selecionados, pelo acadêmico em medicina, auxiliado pelo supervisor do estágio/disciplina $(3,4)$. Geralmente, ela é realizada à beira do leito pelo clínico ou na sala de emergência $(2,4)$. Complicações durante o procedimento são incomuns; quando existentes, decorrem, principalmente, do uso incorreto da técnica (5). Ademais, é um dos procedimentos mais comuns na rotina clínica, sendo essencial que durante a formação

\footnotetext{
*Autor correspondente: karine.ghiggi@gmail.com (Ghiggi K. C.)
} 
acadêmica o discente conheça as características fundamentais das técnicas de punção, no intuito de não gerar complicações que possam colocar a vida do paciente em risco.

Nesse sentido, o presente capítulo ilustra preceitos fundamentais sobre a paracentese. Para tanto, inicialmente, dissertamos sobre aspectos anatômicos do peritônio e da cavidade peritoneal; discorremos sobre a fisiologia envolvida na formação do líquido peritoneal, bem como apresentamos as principais causas relacionadas ao seu acúmulo. Pontuamos, também, indicações e contraindicações para realização da paracentese. Em seguida, ilustramos as duas técnicas de punção (inserção angular e Z-track), os aspectos conexos à coleta do líquido ascítico, sua análise laboratorial e, ainda, tecemos um breve raciocínio clínico frente aos resultados dos exames. Por fim, evidenciamos as principais complicações relacionadas ao uso incorreto da técnica e as particularidades que acompanham à reposição de albumina em paracentese volumosa. Em síntese, apresentamos a técnica da paracentese abdominal e as particularidades que envolvem a análise do líquido ascítico, com intuito de contribuir com o processo de ensino e aprendizagem em medicina, tanto acadêmica quanto profissional.

\section{Princípios e conceitos}

\subsection{Peritônio e cavidade peritoneal}

O peritônio é uma membrana serosa, semipermeável, que reveste grande parte da parede abdominal e, também, recobre a maioria dos órgãos do abdome e da pelve (6). Consiste numa camada de epitélio escamoso simples, denominado mesotélio, coberto por microvilosidades apicais e disposto sobre um fino estroma de tecido conjuntivo (7). $\mathrm{O}$ peritônio apresenta dois folhetos: o folheto parietal, que reveste a superfície da parede abdominal anterior, lateral e posterior, a superfície inferior do diafragma e a pelve; e o folheto visceral, que envolve a maior parte da superfície dos órgãos intraperitoneais e a face anterior dos órgãos retroperitoneais $(6,7)$. Entre os folhetos existe a cavidade peritoneal, um espaço virtual por onde circula, em condições fisiológicas, menos de 100 $\mathrm{mL}$ de um fluido claro, estéril e viscoso, denominado líquido peritoneal (5-8). Nos homens, a cavidade é totalmente fechada, enquanto nas mulheres, há uma abertura para o exterior através das tubas uterinas (7).

A produção e a reabsorção do líquido peritoneal dependem de vários fatores, dentre os quais, a permeabilidade dos capilares peritoneais, as forças hidrostáticas do sistema circulatório, a pressão oncótica do plasma e a reabsorção linfática, sendo, portanto, um transudato fisiológico $(9,10)$. A principal função do líquido peritoneal é a proteção da cavidade abdominal, banhando-a e lubrificando-a, reduzindo, assim, o atrito entre os órgãos e permitindo melhor movimentação durante a digestão $(6,7)$. Outras funções estão relacionadas ao transporte de fluidos e células, ao processo inflamatório, reparo tecidual, na lise de depósitos de fibrina, na proteção contra microrganismos (5-11). Postula-se que um distúrbio de transporte de eletrólitos e fluidos na monocamada de células mesoteliais atua como um importante fator na formação de derrames, com consequente acúmulo de líquido na cavidade abdominal $(7,12,13)$.

\subsection{Ascite}

Ascite é o acúmulo anormal de líquido na cavidade peritoneal; isto é, volumes superiores, no adulto, a $100 \mathrm{~mL}(14,15)$. Assim, ascite não é uma doença, mas uma manifestação clínica comum a várias doenças, síndromes, distúrbios etc., que pode ocorrer por alterações primárias do peritônio ou não $(15,16)$. Especificamente, a 
patogênese envolve diversos mecanismos e, conforme a etiologia, podem sobrepor-se; aproximadamente, $5 \%$ dos pacientes apresentam mais de uma causa para ascite $(2,14,17)$. Entretanto, a maioria dos casos está relacionada a alguma doença hepática crônica descompensada; no ocidente, a hipertensão portal é o principal distúrbio, e em $80 \%$ dos casos devido a cirrose hepática (17). Os principais mecanismos fisiopatológicos envolvidos na formação de ascite (Quadro 1) são (14):

- pressão hidrostática elevada: que se apresenta como hipertensão sinusoidal, alterando as forças de Starling e impelindo líquido para dentro do Espaço de Disse, extravasando para a cavidade abdominal;

- pressão osmótica plasmática reduzida: diversos fatores levam a essa condição, entre as principais estão: hipoalbuminemia, vasodilatação esplâncnica e a desnutrição associada, na maioria dos casos, à doença de base;

- obstrução linfática: que leva a um vazamento linfático intestinal;

- retenção de sódio e água: normalmente associada ao hiperaldosteronismo secundário.

Quadro 1 - Principais causas de ascite.

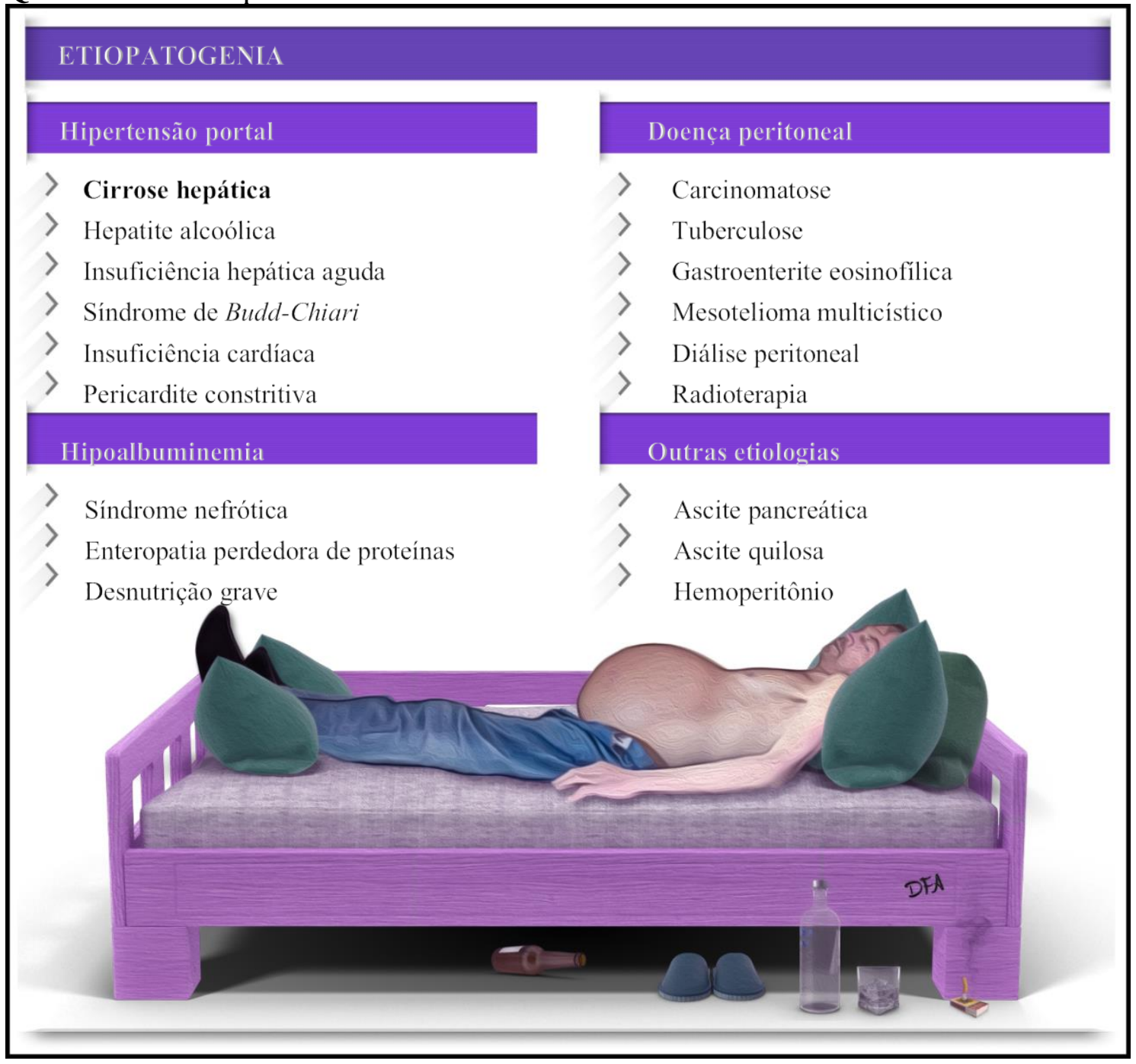

Nota - A ilustração não tem o intuito de estigmatizar o paciente ascítico; foi incorporada ao quadro com finalidade didática, tornando significativo o conhecimento da principal causa de ascite no Brasil, a cirrose hepática (decorrente do consumo excessivo de álcool, principalmente, ou ainda, de hepatite viral). Fonte Elaborado pelos organizadores com adaptações $(15,17)$. 
Além da paracentese, objeto de estudo deste capítulo, a ascite pode ser diagnosticada, em determinados casos, por outros métodos como ultrassonografia (USG) abdominal, exame físico ou tomografia computadorizada (TC) (5,6,12-16). A USG identifica volumes maiores que $100 \mathrm{~mL}$; no exame físico, volumes superiores a 1,5 L são identificados pela manobra da macicez móvel e volumes acima de $5 \mathrm{~L}$, pelas técnicas do piparote e semicírculos de Skoda; a TC, por sua vez, permite o diagnóstico de ascite com segurança e diferencia as coleções líquidas livres das massas sólidas ou císticas; entretanto, devido ao seu alto custo, não costuma ser usada como rotina para tal fim $(5,16)$.

De modo geral, a ascite torna-se clinicamente detectável quando, pelo menos, $1500 \mathrm{~mL}$ se acumulam; todavia, mais de $5000 \mathrm{~mL}$ podem acumular-se na cavidade e causar distensão abdominal maciça (16,17). Ascite pode ser graduada de acordo com a quantidade de líquido na cavidade abdominal (15):

- Grau I: leve, identificada somente por USG abdominal;

- Grau II: moderada, determinando distensão abdominal;

- $\quad$ Grau III: acentuada, com distensão abdominal maciça.

Além disso, a ascite pode ser classificada em:

- $\quad$ ão complicada: ascite não relacionada à peritonite bacteriana espontânea (PBE), síndrome hepatorrenal ou refratária;

- recidivante: ascite que recorre pelo menos três vezes em 12 meses, a despeito de restrição de sódio e dose adequada de diurético;

- refratária: ascite que não pode ser mobilizada ou cuja recorrência precoce não pode ser prevenida por terapia;

- diurético-resistente: falta de resposta ao tratamento com restrição de sódio e diuréticos;

- diurético-intratável: desenvolvimento de complicações associadas à diureticoterapia impedem a continuação do tratamento (p. ex., injúria renal aguda).

\section{Indicações e contraindicações}

Como regra, a paracentese é exame obrigatório para todo paciente hospitalizado com ascite sem diagnóstico $(2,12,15)$. Em geral, o procedimento é indicado (Quadro 2) para confirmar a presença de ascite, determinar se o líquido acumulado está infectado e, ainda, drenar grandes volumes $(1,2,15)$. Já as contraindicações podem ser absolutas ou relativas $(15,18)$. Muitos pacientes submetidos à paracentese terão coagulopatia basal ou trombocitopenia como resultado da doença hepática subjacente; todavia, a incidência de complicações hemorrágicas significativas nesses pacientes é baixa $(1,2,15)$. Em outras palavras, tais condições devem ser encaradas como contraindicações relativas, sendo necessário avaliação particular do caso. Cuidados adicionais devem ser tomados nas seguintes condições:

- $\quad$ gestação em curso;

- visceromegalias;

- $\quad$ aderências abdominais;

- $\quad$ obstrução intestinal importante;

- retenção vesical.

Em geral, são poucos os casos em que a paracentese não pode ser realizada (15). Na necessidade de realizar paracentese em pacientes com obstrução intestinal ou retenção urinária, deve-se, idealmente, realizar esvaziamento gástrico ou vesical, respectivamente, antes do procedimento, a fim de reduzir os riscos. 
Quadro 2 - Principais indicações e contraindicações da paracentese.

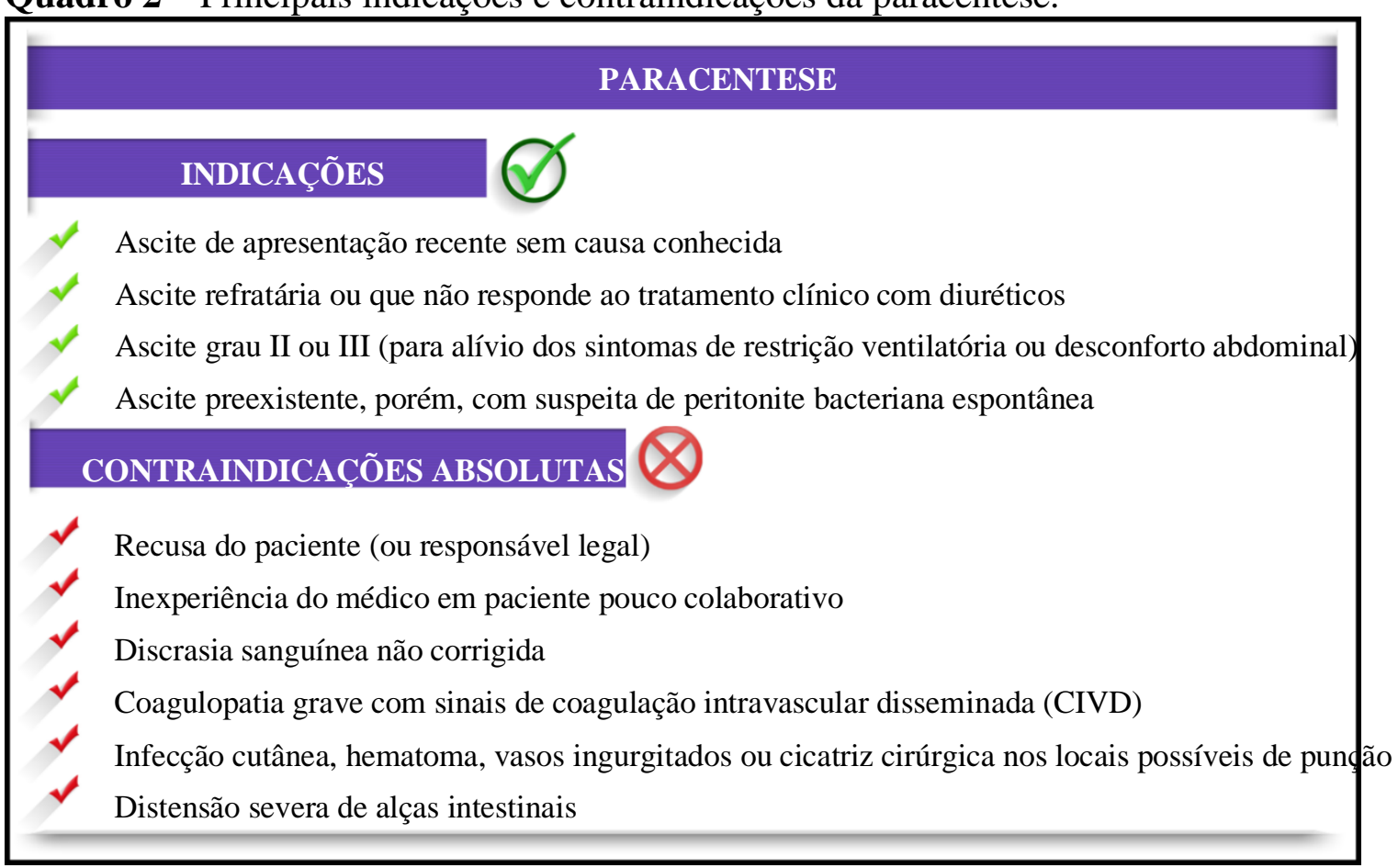

Fonte - Elaborado pelos organizadores com adaptações $(15,17)$.

Importante mencionar que, durante a avaliação estática do abdome, é fundamental observar se há alterações anatômicas, deformidades ou sinais, além dos supracitados, que possam, de alguma forma, contraindicar o procedimento.

\section{Preparação}

\subsection{Explicação do procedimento}

O tratamento da ascite visa primariamente o conforto do paciente. Diante de tal percepção, devemos informá-lo, em linguagem clara e objetiva, que o procedimento não será doloroso, tampouco causará desconforto, tentando, ao mesmo tempo, obter a sua colaboração, sobretudo nesse momento delicado, uma vez que o desenvolvimento de ascite em pacientes com cirrose, por exemplo, está associado a um mau prognóstico, com mortalidade de $40 \%$ em um ano e $50 \%$ em dois anos, motivo pelo qual deve-se considerar, em determinados casos, a indicação de transplante hepático (15).

\subsection{Checklist}

Após obter o consentimento verbal do paciente ou de seu responsável legal, deve-se:

- $\quad$ separar o equipamento de proteção individual (EPI): uso indispensável para o médico eleito para o procedimento, quanto para seu auxiliar (procure a ajuda de um assistente para monitorar o paciente, auxiliar com os frascos de amostra e/ou coleta etc.);

- $\quad$ reunir os materiais que serão utilizados em todas as etapas da paracentese (Figura 1);

- $\quad$ preencher o pedido dos exames necessários;

- rotular os frascos de coleta com os dados básicos do paciente.

A seguir, apresentamos o checklist completo com os materiais necessários para a realização da paracentese (18): 


\section{CHECKLIST}

$\checkmark \quad$ Par de luvas estéril

$\checkmark$ Avental descartável estéril

$\checkmark$ Gorro e propés

$\checkmark \quad$ Máscara cirúrgica

$\checkmark$ Óculos de proteção

$\checkmark$ Ultrassom portátil

$\checkmark$ Capa plástica estéril para USG

$\checkmark$ Gel para USG

$\checkmark$ Caneta (para marcação da pele)

$\checkmark$ Pacote de gaze estéril

$\checkmark$ Pinça estéril (para antissepsia)

$\checkmark$ Clorexidina alcoólica a $0,5 \%$

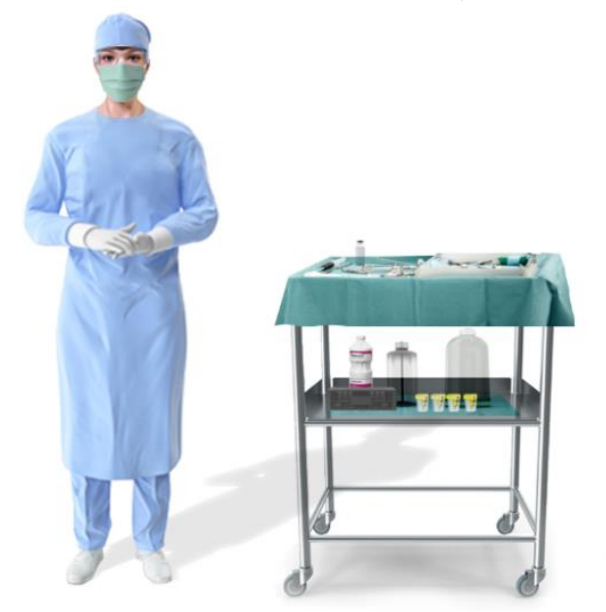

$\checkmark$ Cuba pequena estéril ou frasco de $80 \mathrm{~mL}$ estéril

$\checkmark$ Campo fenestrado estéril $50 \times 50 \mathrm{~cm}$

$\checkmark$ Agulha de aspiração $40 \times 1,2 \mathrm{~mm}$ (18G)

$\checkmark$ Agulha de infiltração 30 x 0,7 mm (22G)

$\checkmark$ Seringa de 5 ou $10 \mathrm{~mL}$ para anestesia local

$\checkmark \quad$ Seringa de $20 \mathrm{~mL}$ para coleta

$\checkmark$ Lidocaína a 2\% sem vasoconstritor

$\checkmark \quad$ Lâmina de bisturi $n^{\circ} 11$ (se paracentese terapêutica)

$\checkmark$ Cateter sobre agulha $n^{\circ} 14$ ou 16 (p. ex., Jelco ${ }^{\circledR}$ )

$\checkmark$ Equipo de soro (se paracentese terapêutica)

$\checkmark \quad$ Torneira de 3 vias (se paracentese terapêutica)

$\checkmark$ Tubos de coleta (4 ou mais)

$\checkmark \quad$ Frasco coletor estéril de $80 \mathrm{~mL}$ (citologia oncótica)

$\checkmark \quad$ Frasco de drenagem (se paracentese terapêutica)

$\checkmark$ Curativo adesivo (compressivo)

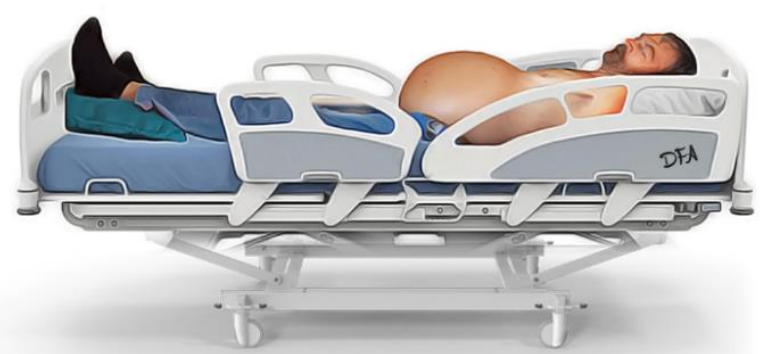

Figura 1 - Materiais necessários para paracentese.

Nota: Preferencialmente utilize os tubos de coleta apropriados (p. ex., tubos de tampa branca para análise bioquímica e frascos de hemocultura).

Fonte - Elaborada pelos organizadores com adaptações (18).

\subsection{Posicionamento do paciente e sítio de punção}

O posicionamento correto e confortável do paciente, bem como sua colaboração é fundamental para o sucesso do procedimento. O paciente deve estar em decúbito dorsal horizontal (Figura 2A), na beira do leito, próximo do médico (1). Nos casos de ascites graus I e II ou necessidade de maior escoamento, é necessário elevar a cabeceira da cama em $30^{\circ}$ a $45^{\circ}$ (Figura 2B), mas de maneira que fique cômodo ao paciente $(1,15)$. Da mesma forma, o paciente também pode ficar inclinado em $30^{\circ}$ para um dos lados, se for realizada a paracentese em um dos quadrantes inferiores (laterais) do abdome, de maneira a escoar o líquido ascítico para o lado a ser puncionado. Conforme a disponibilidade do serviço, a USG abdominal à beira do leito pode auxiliar na demarcação e, também, guiar a punção. O exame mostra a região onde há maior acúmulo de líquido livre (Figura 3) e com menor risco de perfuração incidental de vasos ou vísceras $(5,15)$. Quando disponível, o exame deve ser utilizado, sobretudo em ascite graus I ou II. 


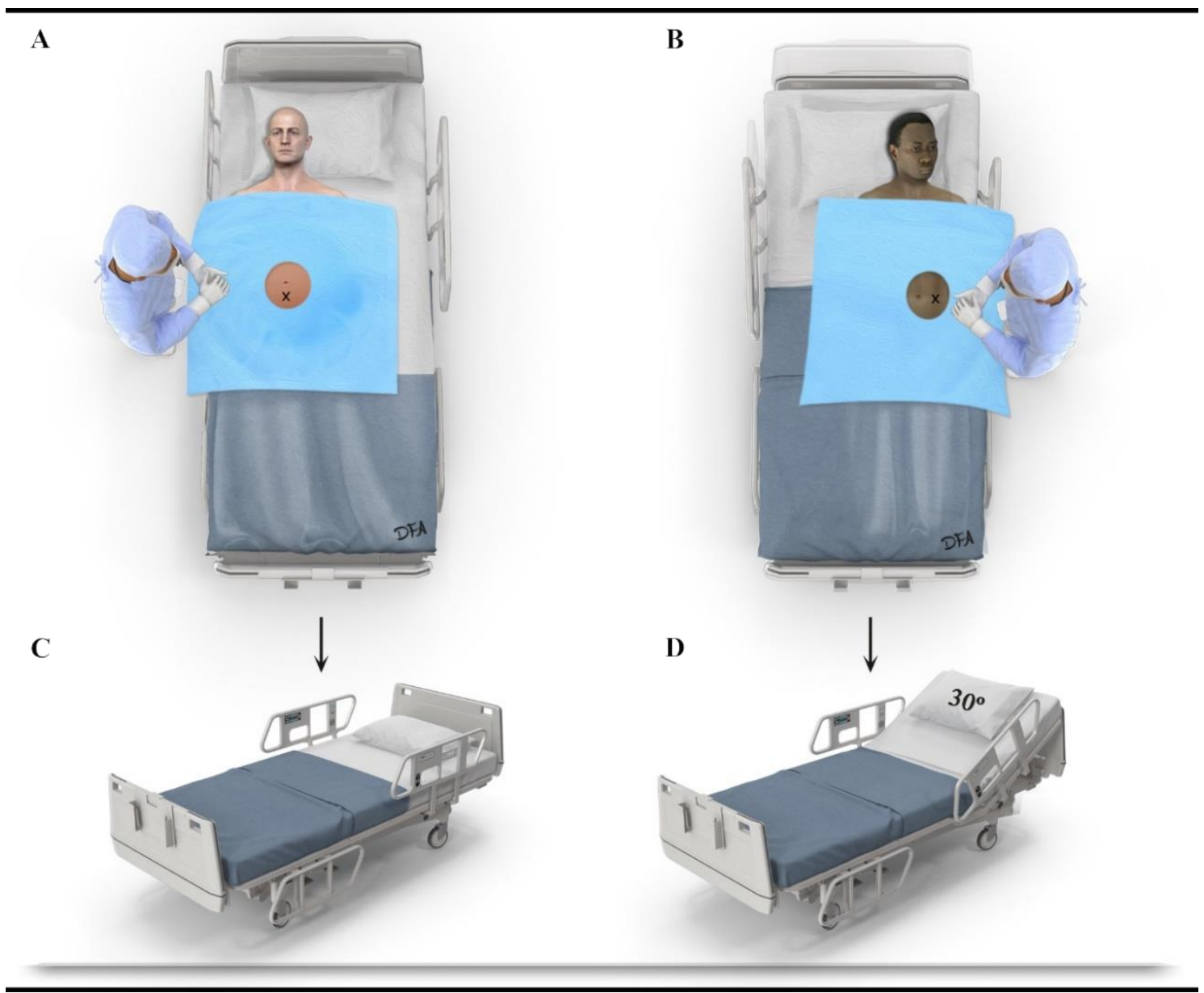

Figura 2 - Posicionamento e ajuste da cabeceira conforme o grau ascítico.

A. Paciente com ascite Grau III, em decúbito dorsal horizontal, próximo do médico, para punção na linha mediana do hipogástrio. B. Paciente com ascite grau I, próximo do médico, para punção em QIE do abdome. C. Cabeceira na horizontal. D. Cabeceira elevada a $30^{\circ}$.

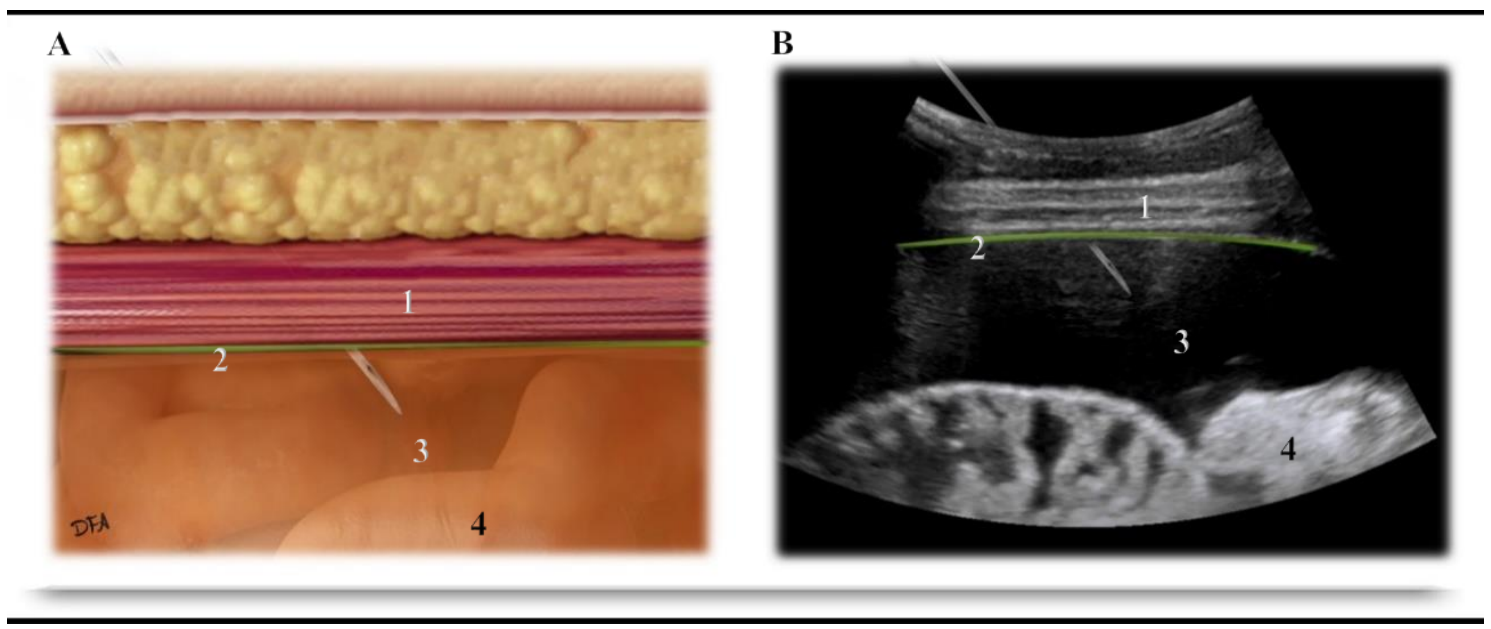

Figura 3 - Punção guiada pelo ultrassom.

A. Desenho esquemático da trajetória do cateter. B. Imagem ultrassonográfica correspondente.

(1) Camada muscular; (2) Peritônio parietal; (3) Líquido ascítico; (4) Intestino.

A punção é geralmente realizada no QIE, mas pode ser feita no quadrante inferior direito ou na linha mediana do hipogástrio (1). A escolha desses pontos se dá por questões anatômicas de escoamento e de acúmulo de líquido peritoneal (Figura 4). 


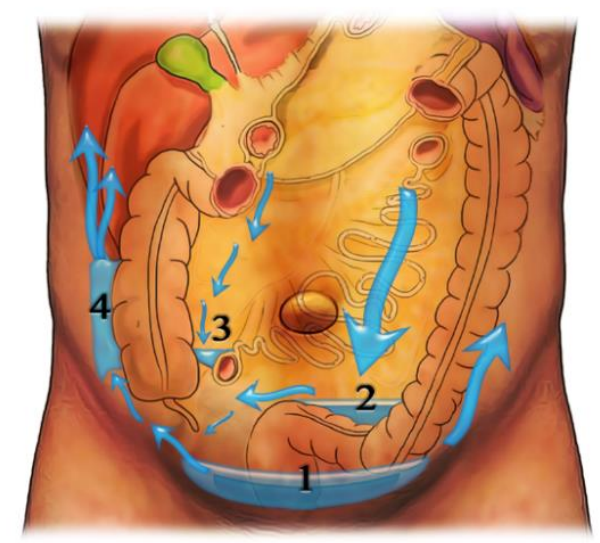

Figura 4 - Direção do escoamento e acúmulo do líquido peritoneal.

Direção do escoamento do líquido peritoneal (setas) e o acúmulo em pontos específicos: (1) fundo de saco posterior; (2) sobre o mesocólon sigmoide; (3) quadrante inferior direito; (4) goteira parietocólica direita.

Dá-se preferência pelo QIE por menor chance de complicação, pois nessa topografia, encontramos o sigmoide e, sendo ele mais flexível que o ceco, torna a técnica menos arriscada à esquerda em caso de distensão abdominal. O QID é menos desejável, pois pode ter uma cicatriz de apendicectomia ou um ceco cheio de gás em pacientes que fazem uso de lactulose (15). Nas linhas paramedianas do abdome, junto ao músculo reto abdominal, encontram-se as artérias epigástricas (esquerda e direita) e, portanto, estas áreas devem ser evitadas (a artéria pode ter $3 \mathrm{~mm}$ de diâmetro e pode sangrar massivamente se perfurada com uma agulha de grande calibre) (Figura 5). Além disso, cicatrizes cirúrgicas podem estar associadas a aderências intestinais na parede abdominal, colocando o paciente em risco de perfuração se a paracentese for realizada perto de uma cicatriz; veias visíveis também devem ser evitadas.

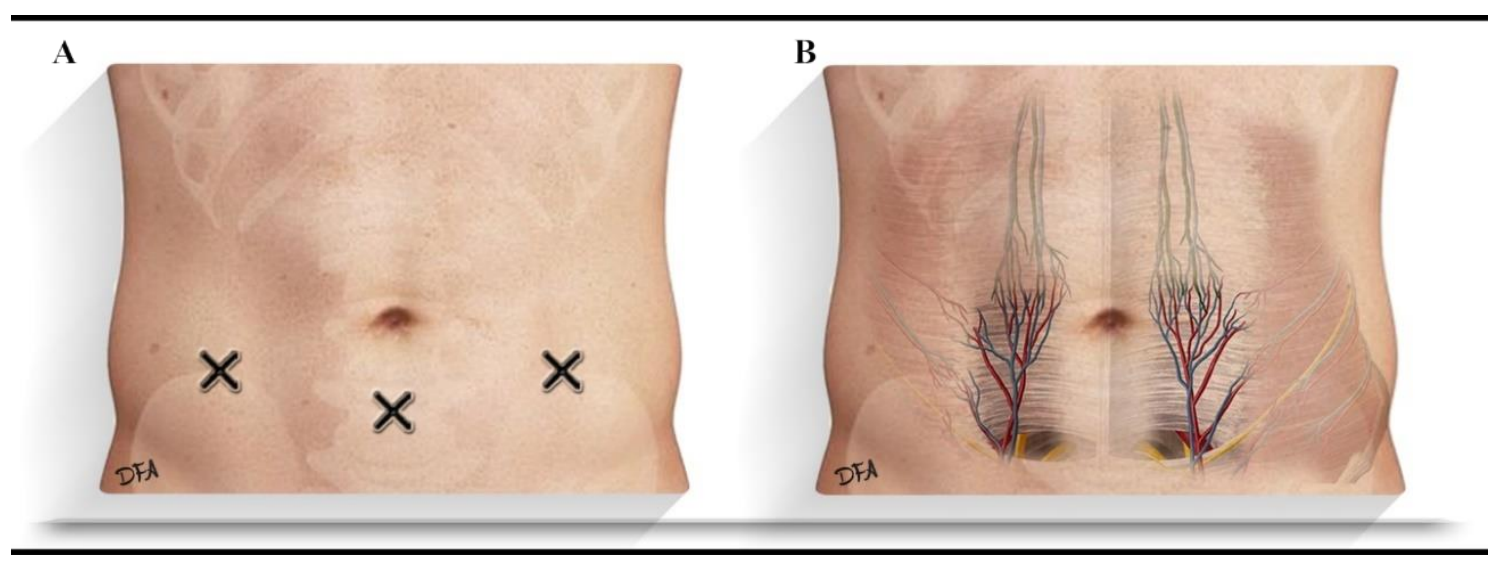

Figura 5 - Locais de punção e localização da artéria epigástrica inferior.

A. Locais de punção (da esquerda para direita: QID, hipogástrio e QIE). B. Localização anatômica da artéria epigástrica inferior (esquerda e direita).

\section{Procedimento}

Estando o paciente devidamente posicionado no leito, deve-se marcar com um "X" o local escolhido para punção utilizando uma caneta de pele (Figura 6). 


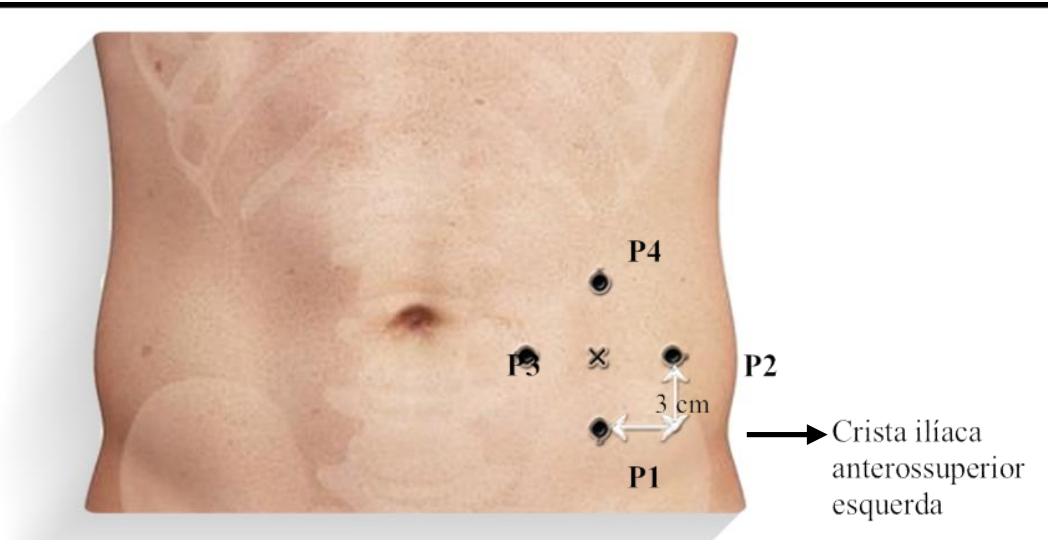

Figura 6 - Técnica de demarcação do sítio de punção.

Utilizando técnica de palpação, localize a crista ilíaca anterossuperior esquerda (sendo esse o referencial anatômico inicial). Após, marque o primeiro ponto (P1) a $3 \mathrm{~cm}$ (duas polpas digitais) no sentido medial da crista ilíaca. Marque o ponto 2 (P2) a $3 \mathrm{~cm}$ no sentido cefálico da crista ilíaca. Seguindo esse mesmo raciocínio, marque os pontos 3 e 4 (P3 e P4) conforme a figura. Em síntese, serão 4 marcas, sendo duas na linha horizontal (esquerda e direita) e duas na linha vertical (superior e inferior). Por fim, no centro dessas marcas, faça um " $X$ " (marque suavemente), sendo este o ponto de punção.

O ponto de punção " $X$ " será apagado na antissepsia, permanecendo apenas as 4 marcas (P1, P2, P3 e P4). Feito isso, deve-se proceder da seguinte forma:

- $\quad$ higienização e paramentação: higienizar as mãos e antebraços, preferencialmente com esponja/escova de gluconato de clorexidina (princípio ativo) solução degermante a $2 \%$, seguido por secagem com compressa estéril; ou, na ausência desses materiais, higienizar as mãos com água e sabão neutro, seguido por secagem rigorosa com folha de papel e uso de álcool gel;

- calçar luvas estéreis utilizando técnica cirúrgica;

- $\quad$ promover antissepsia do local de infiltração com solução de clorexidina alcoólica a $0,5 \%$;

- colocar o campo fenestrado estéril.

- $\quad$ aplicar o anestésico local;

- $\quad$ executar a técnica.

Os três últimos itens serão apresentados, em maiores detalhes, nos tópicos a seguir.

\subsection{Antissepsia do campo operatório}

Refere-se ao preparo pré-operatório da pele do paciente utilizando gluconato de clorexidina solução alcoólica. Deve-se aplicar o antisséptico na área da punção com gaze estéril embebida em solução de clorexidina alcoólica $0,5 \%$. O " $\mathrm{X}$ " demarcado deve ser apagado, no entanto, não devemos remover totalmente os pontos colaterais, pois eles vão servir de orientação para a posição original do "X", que estará no centro das quatro marcas. Portanto, a esterilização periférica não deve ser tão intensa para não apagar todas as marcas. Em seguida, deve-se posicionar os campos na área a ser puncionada.

\subsection{Anestesia}

Realizar infiltração do anestésico local com agulha fina. Utiliza-se lidocaína a 2\% na dose indicada para o paciente. Recomenda-se infiltrar, aproximadamente, $1 \mathrm{~mL}$ do anestésico no local de entrada na epiderme (botão anestésico); após, anestesiar os tecidos mais profundos avançando lentamente a agulha, alternando entre injetar o anestésico e 
aspirando para assegurar que a agulha não penetrou em uma estrutura vascular. Ao sentir uma súbita perda da resistência da agulha ao entrar na cavidade peritoneal, já é possível aspirar o líquido na seringa. Então, deve-se injetar de 3 a $5 \mathrm{~mL}$ para anestesiar o peritônio parietal que é altamente sensível. Assim, usualmente será utilizado, de 5 a $10 \mathrm{~mL}$ de lidocaína.

\subsection{Punção percutânea}

Realizar uma pequena punção no local de inserção com um cateter sobre agulha número 14 ou 16 (ou bisturi com uma lâmina número 11 facilita o avanço do cateter de paracentese através da epiderme). É conveniente colocar uma seringa no conjunto do cateter. A punção é realizada apoiando-se a ponta do cateter no local anestesiado, introduzindo cuidadosamente o cateter até sentir uma leve resistência, que é facilmente vencida, atingindo a cavidade abdominal. Para a introdução do cateter, existem duas técnicas especiais que evitam a formação de canal para saída de líquido peritoneal após a retirada do cateter; são elas: técnica de inserção angular e técnica em Z (Z-track).

\subsubsection{Técnica de inserção angular}

Consiste em inserir o cateter de forma inclinada em ângulo de $45^{\circ}$ (Figura 7). Ao perfurar a pele, a direção é mantida através dos tecidos subcutâneos até alcançar a cavidade. Essa técnica permite que, após a retirada do cateter, as fibras da musculatura abdominal bloqueiem a saída de líquido pelo canal formado pela passagem do cateter.

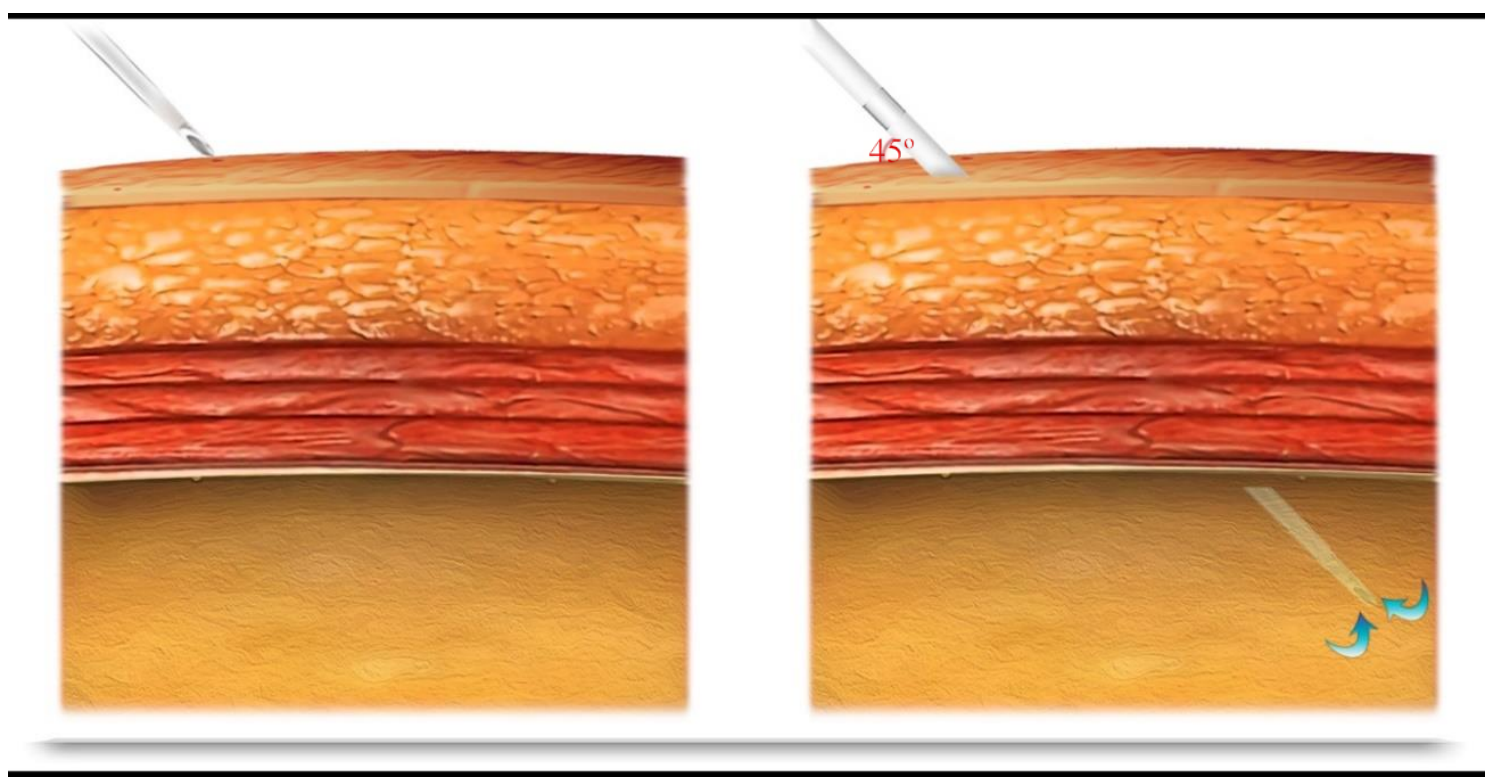

Figura 7 - Técnica de inserção angular.

Introduza o cateter lentamente, utilizando o mesmo trajeto da anestesia. Observe (à direita) o ângulo formado entre a pele e o cateter, que deve ser de $45^{\circ}$.

\subsubsection{Técnica em Z (Z-track)}

Consiste em tracionar a pele, em direção inferior (caudal), com os dedos, em aproximadamente $2 \mathrm{~cm}$ e introduzir o cateter em ângulo de $90^{\circ}$ com a pele. Após soltarmos a pele, o ponto de entrada retorna a sua posição original, ficando em angulação diferente do local de punção do peritônio. Assim, diminui-se o risco de fuga de líquido da cavidade através do canal formado pela introdução da agulha. Observe a Figura 8 a seguir: 


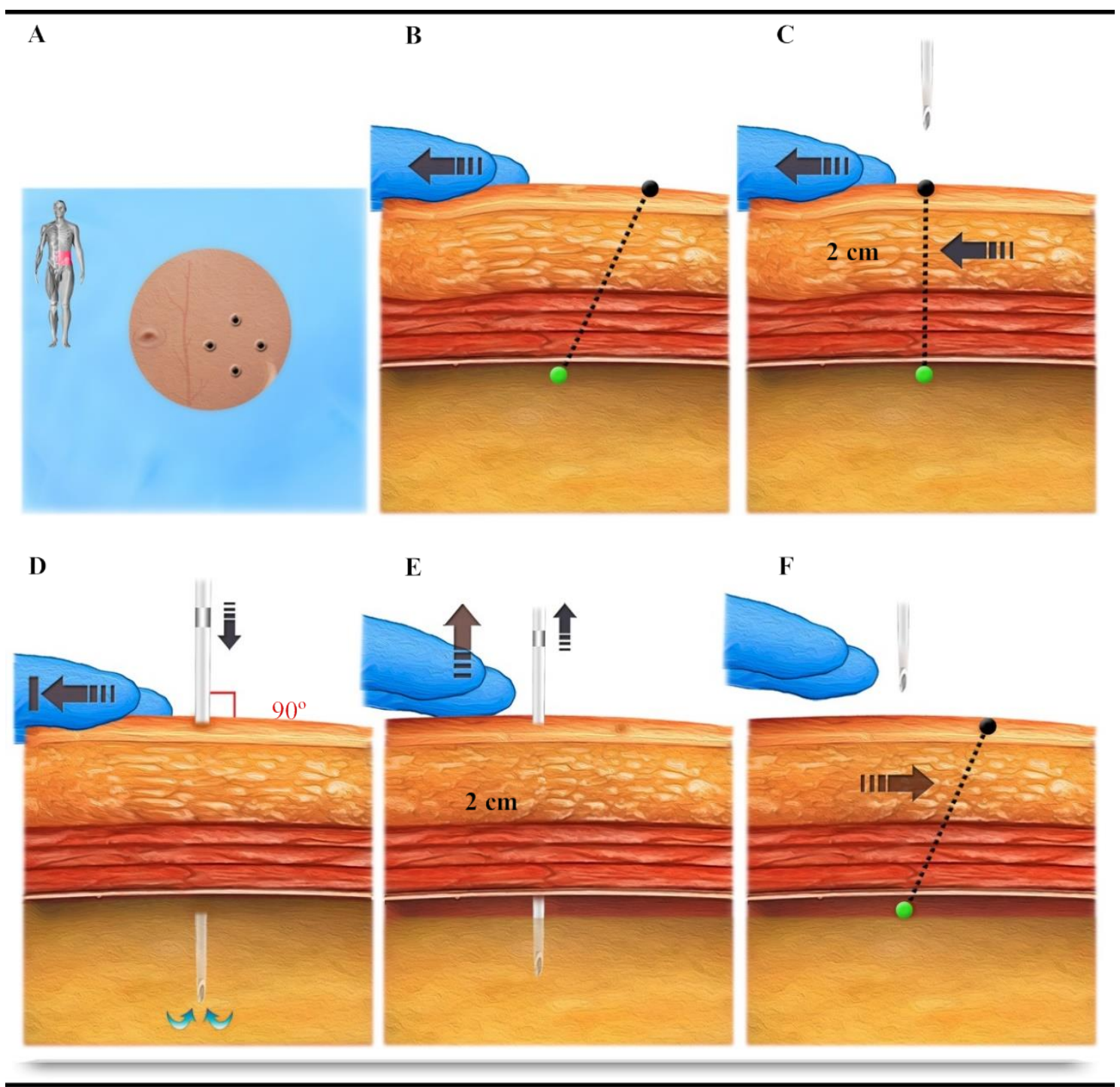

Figura 8 - Ilustração da técnica em Z (não guiada pelo ultrassom).

A. Localização do sítio de punção (no centro das 4 marcas). B. Seta sobre os dedos indicando aproximação da mão não-dominante; círculo preto (acima) e verde (abaixo) representando os pontos de entrada e saída do cateter, respectivamente. C. Setas apontando para esquerda indicando que a pele, o tecido subcutâneo e em menor grau, o tecido muscular, estão sendo tracionados $(2 \mathrm{~cm})$ em direção/sentido caudal antes da realização da punção. Novamente, os círculos indicam os pontos perfurados pelo cateter e evidenciam a horizontalidade do trajeto. D. Inserção do cateter em ângulo de $90^{\circ}$ com a pele. E. Seta sobre os dedos indicando a soltura da pele e seta menor (ao lado do cateter), indicando a retirada do cateter. F. Demonstração das forças exercidas pelas fibras musculares da parede abdominal que, após retirada dos dedos, retornaram à posição inicial, evitando assim, o escape do líquido.

A técnica em $Z$ (não guiada pelo ultrassom) consiste em:

- $\quad$ primeiramente, segure a seringa e o eixo da agulha com a mão dominante. Coloque a mão não-dominante sobre a pele do paciente (isso ajuda a dirigir suavemente a agulha através do tecido subcutâneo);

- posteriormente, avance a agulha aos poucos (2 a $3 \mathrm{~mm}$ ), puxando intermitentemente o êmbolo para avançar. Ao sentir uma súbita perda de resistência à medida que a agulha entra na cavidade peritoneal, o líquido ascítico enche a seringa;

- em seguida, guie cuidadosamente o cateter sobre a agulha e retire a agulha, deixando o cateter em posição;

- paracentese diagnóstica: coloque uma seringa de $20 \mathrm{~mL}$ no cateter e retire a quantidade necessária conforme os exames previamente solicitados; 
- paracentese terapêutica: coloque o equipo de conexão no centro do cateter e, em seguida, conecte ao recipiente; os recipientes adicionais podem ser cheios conforme necessário.

- quando a quantidade desejada do fluido for retirada, remover rapidamente o cateter; aplique uma solução estéril oclusiva e pressione o local.

\section{Complicações}

As complicações graves relacionadas à paracentese abdominal são raras $(1,2,4-9,15,18)$. Assim, os benefícios do procedimento, em pacientes com indicação apropriada, quase sempre superam os riscos $(4,18)$. O extravasamento do líquido ascítico é a complicação mais frequente e decorre, principalmente, do uso incorreto da técnica (18). Em síntese, as complicações descritas na literatura são:

- $\quad$ vazamento persistente de líquido ascítico no local da punção;

- hemoperitônio;

- $\quad$ hemorragia (p. ex., punção da artéria epigástrica inferior);

- pneumoperitônio;

- $\quad$ perfuração (p. ex., bexiga, estômago, alça intestinal ou útero gravídico);

- $\quad$ disfunção hemodinâmica (em paracentese volumosa);

- $\quad$ infecções tardias (p. ex., celulite ou erisipela);

- $\quad$ infecção retrógrada do líquido ascítico;

- $\quad$ peritonite;

- hematomas da parede abdominal;

- $\quad$ hipotensão pós-paracentese;

- hiponatremia dilucional;

- $\quad$ síndrome hepatorrenal.

\section{Coleta do material e investigação}

Obtido o líquido ascítico, deve-se examinar seu aspecto macroscópico e realizar a análise laboratorial; essa avaliação ajuda a determinar se a ascite é devido à hipertensão portal ou a outro processo (p. ex., neoplasia maligna ou infecção) $(1,4,15,17-19)$. Para a análise do líquido ascítico são necessários, no mínimo, 4 tubos de coleta, objetivando a investigação citológica, bioquímica e bacteriológica (cultura).

\subsection{Aparência macroscópica e condições associadas}

A aparência anormal do fluido ascítico por inspeção visual é altamente sensível para a detecção de algumas condições $(15,20,21)$. O Quadro 3 a seguir apresenta algumas correlações. 
Quadro 3 - Aparência do líquido ascítico e as condições associadas (ou sugestivas).

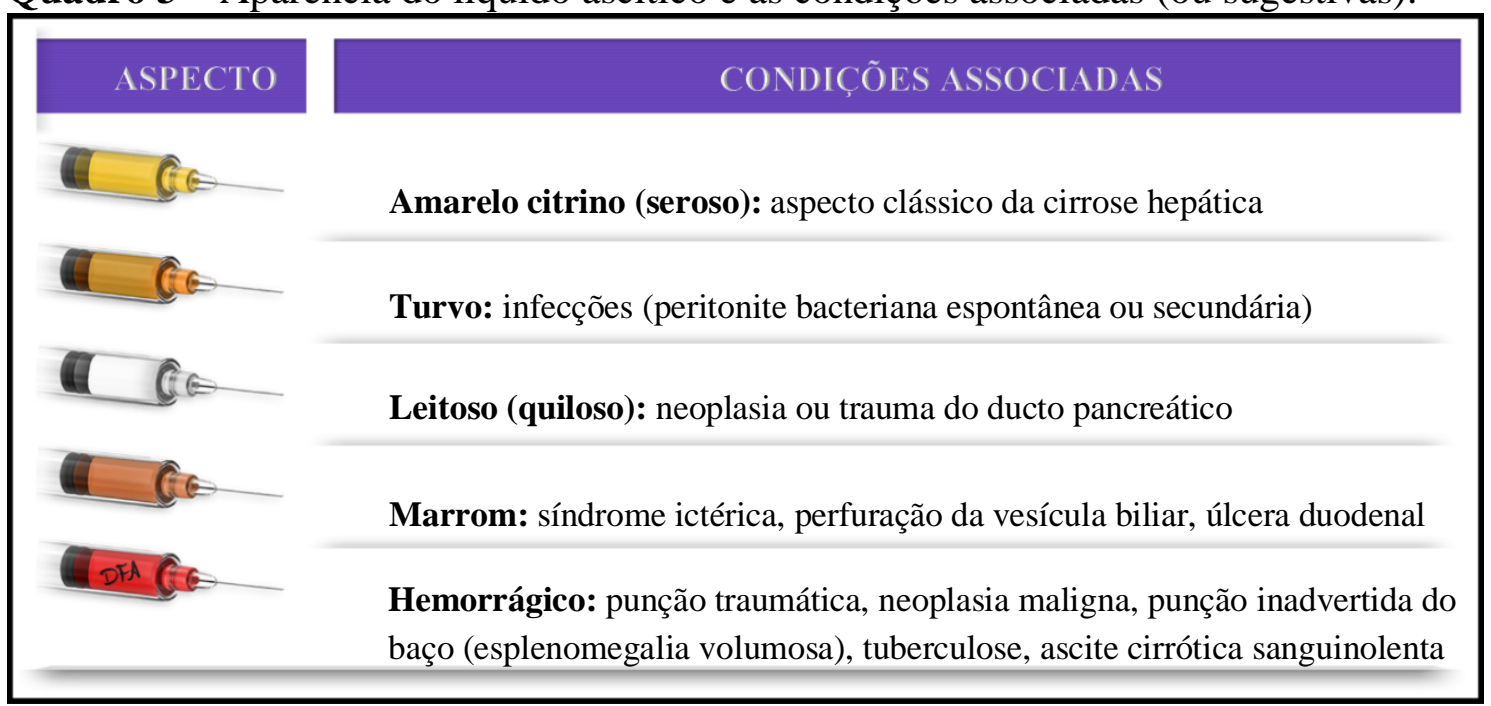

Fonte - Elaborado pelos autores com adaptações (15,20,21).

\subsection{Citologia e citometria: $1^{\circ}$ frasco}

Em soro fisiológico (SF) $0,9 \%$ e $1 \mathrm{~mL}$ de heparina não fracionada. A contagem de leucócitos polimorfonucleares (PMN) é importante no diagnóstico de PBE no paciente cirrótico, independente da cultura, pois pode causar sequelas graves ou morte. As bactérias mais comuns são Escherichia coli e Klebsiella pneumoniae (Gram-negativos) e Streptococcus pneumoniae (Gram-positivos); geralmente apenas um único organismo está envolvido (Figura 9) (17). Pode-se considerar PBE quando a contagem de leucócitos PMN for maior que 250 células $/ \mathrm{mm}^{3}(17,19)$.

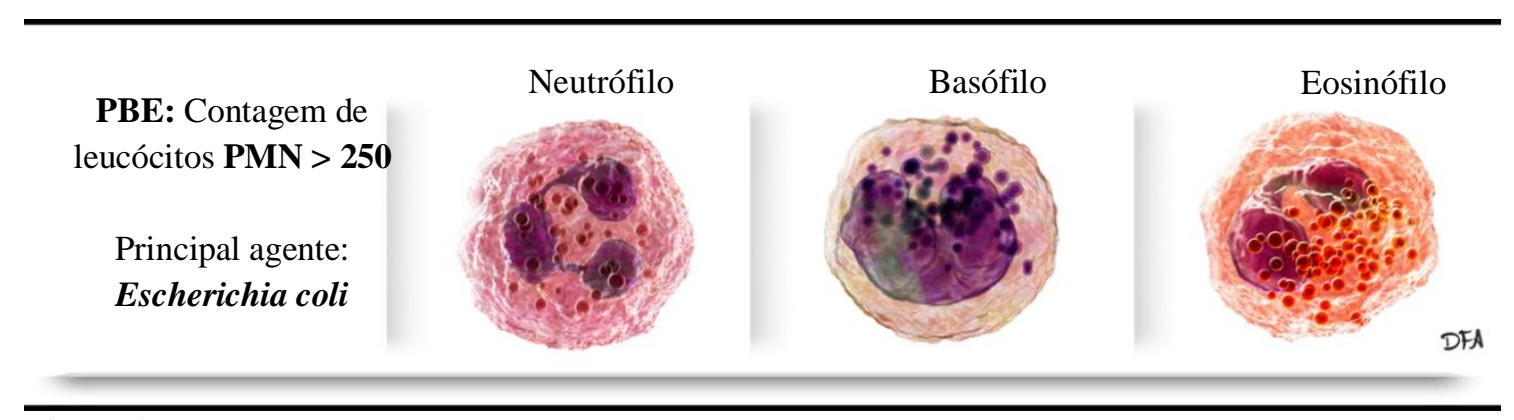

Figura 9 - Diagnóstico de peritonite bacteriana espontânea.

\subsection{Gradiente de albumina sérica e albumina do líquido ascítico}

A dosagem do Gradiente de Albumina Soro-ascite (GASA) é crucial no diagnóstico da etiologia da ascite, principalmente relacionada à hipertensão portal (Quadro 4). O GASA é a diferença entre a albumina do soro e a albumina do líquido ascítico; por isso, devem ser colhidos simultaneamente $(15,19)$. Gradiente $\geq 1,1 \mathrm{~g} / \mathrm{dL}$ (transudato) sugere hipertensão portal; gradiente $<1,1 \mathrm{~g} / \mathrm{dL}$ (exsudato) afasta hipertensão portal e sugere doença peritoneal $(15,22)$. 
Quadro 4 - Patologias relacionadas ao valor do GASA.

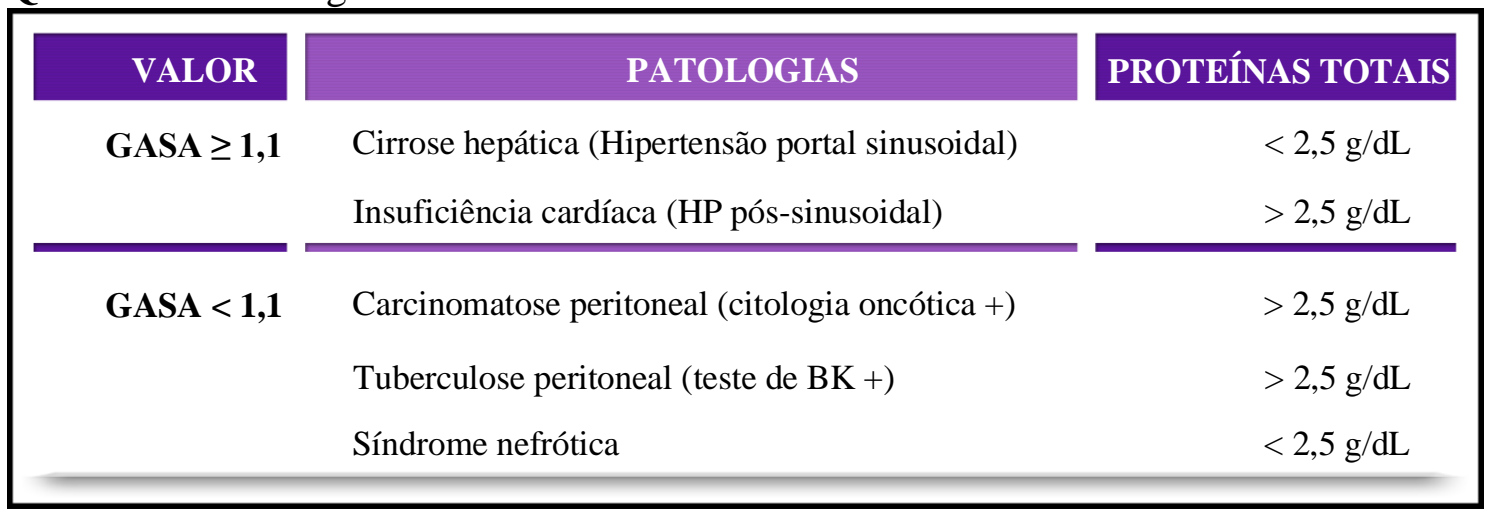

Fonte - Elaborado pelos autores com adaptações $(15,22)$.

\subsection{Citologia oncótica: $2^{\circ}$ frasco}

Frasco com metade de álcool ou formaldeído e metade de líquido ascítico. A amostra deve ser encaminhada ao anatomopatológico; contribuindo para o diagnóstico diferencial das neoplasias malignas peritoneais, principalmente metastáticas.

\subsection{Cultura: $3^{\circ}$ frasco}

De preferência no frasco de hemocultura, colocar $10 \mathrm{~mL}$ de líquido ascítico à beira do leito. Se o frasco de hemocultura não estiver disponível, acrescentar ao frasco SF 0,9\%. Solicitar culturas para bactérias; e, mediante suspeita, fungos e tuberculose.

\subsection{Bioquímica: $4^{\circ}$ frasco}

Frasco sem aditivos, contendo apenas amostra do líquido peritoneal. Deve-se, então, solicitar glicose, $\mathrm{pH}$, proteínas totais, albumina, desidrogenase láctica (DHL), triglicerídeos, fosfatase alcalina. $\mathrm{Na}$ primeira análise: amilase, antígeno carcinoembrionário (CEA) e adenosina deaminase (ADA).

\section{Parâmetros analisados e comentários}

Importante frisar que a medida da concentração total de proteínas do líquido ascítico é fundamental, pois pacientes com concentrações inferiores a 1,5 g/dL têm maior risco de desenvolvimento de PBE e podem beneficiar-se de profilaxia antibiótica (Quadro 5) $(15,21)$. 
Quadro 5 - Comentários sobre os parâmetros bioquímicos analisados no líquido peritoneal.

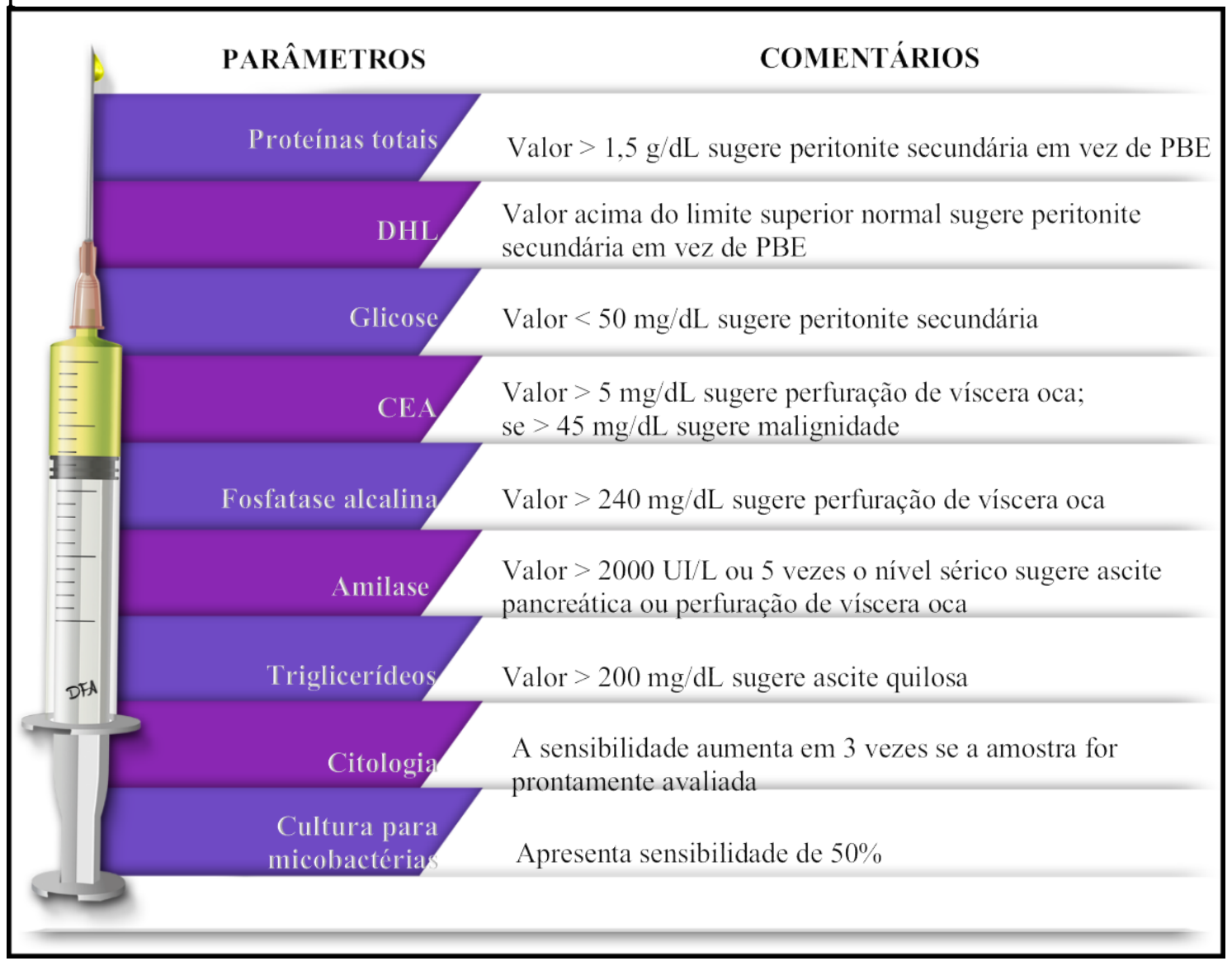

Fonte - Elaborado pelos autores com adaptações $(15,22)$.

\section{Reposição de albumina}

A reposição de albumina $20 \%$ deverá ser realizada após paracentese de grande volume, acima de $6 \mathrm{~L}$; sendo 6 a $8 \mathrm{~g} / \mathrm{L}$ drenado (23). A reposição deve ser calculada pelo volume total retirado; se forem retirados $6 \mathrm{~L}$, deverá ser reposta 36 a $48 \mathrm{~g}$ de albumina $(23,24)$. A infusão de albumina ocorre concomitante ou logo após o procedimento, com velocidade de $1 \mathrm{~mL} / \mathrm{min}(15,18,23)$. Pode-se remover até $5 \mathrm{~L}$ sem consequências hemodinâmicas imediatas (15).

\section{Considerações finais}

Paracentese é um procedimento médico simples, de fácil execução, baixo custo e que pode ser realizado à beira do leito; frequentemente realizado no paciente cirrótico descompensado. A avaliação inicial do paciente deve incluir história, exame físico, ultrassonografia abdominal e avaliação laboratorial das funções hepática e renal, eletrólitos séricos e urinários. A utilização da USG é muito útil, tanto na demarcação do local de punção, quanto na inserção do cateter de paracentese. A complicação mais comum, embora infrequente, é o vazamento de líquido ascítico no local puncionado; hemorragia intraperitoneal ou perfuração de alças intestinais durante o procedimento são as complicações mais graves, ocorrendo raramente (Quadro 6). 
Quadro 6 - Tópicos em destaque no capítulo.

\section{PARACENTESE}

Indicada em pacientes com ascite refratária; de grande volume; suspeita de infecção; 1
cirróticos hospitalizados.

O posicionamento correto e confortável do paciente auxilia no sucesso do procedimento 3

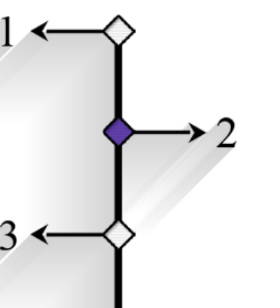

A hipertensão portal é o principal distúrbio causador de ascite, geralmente por cirrose hepática. (não negligencie essa etapa).

Sempre que disponível, utilize o aparelho de ultrassom para auxiliar na demarcação e guiar a punção.

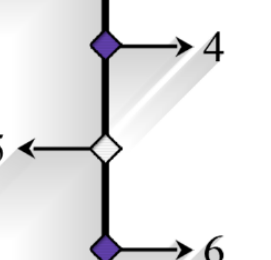

Na ausência de contraindicações, dê preferência pela punção no QIE por menor chance de complicação.

Considerar PBE quando a contagem de $\mathrm{PMN}$ for maior que 250 células $/ \mathrm{mm}^{3}$ no líquido ascítico.

Deve-se subtrair 1 leucócito a cada 750 hemácias e 1 PMN a cada 250 hemácias.

Infusão de albumina 20\% ocorre junto ou 9 logo após paracentese volumosa, com velocidade de $1 \mathrm{~mL} / \mathrm{min}$.

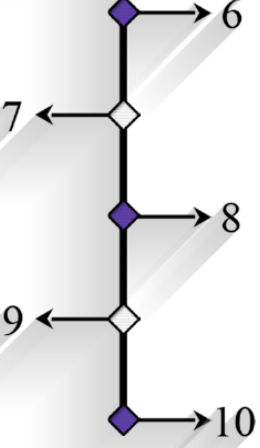

GASA é crucial no diagnóstico da etiologia da ascite, principalmente relacionada a hipertensão portal.

Lembre-se que a presença de ascite é considerada, muitas vezes, um sinal de mau prognóstico ao paciente.

\section{Referências}

1. Thomsen TW, Shaffer RW, White B, Gary GS. Paracentesis. N Engl J Med 2006; 355(19):e21.

2. Moore KP, Wong F, Gines P, Bernardi M, Ochs A, Salerno F, et al. The management of ascites in cirrhosis: Report on the Consensus Conference of the International Ascites Club. Hepatol 2003; 38(1):258-66.

3. Conselho Federal de Medicina [Internet]. Código de ética do estudante de medicina [acesso em 15 nov 2019]. Disponível em: www.flip3d.com.br/web/pub/cfm/index9/?numero=23\&edicao=4442\#page/4.

4. Fukunaga N, Shomura Y, Nasu M, Okada Y. Chylous ascites as a rare complication after abdominal aortic aneurysm surgery. South Med J 2011;104: 365-7.

5. Sakai H, Sheer TA, Mendler MH, Runyon BA. Choosing the location for nonimage guided abdominal paracentesis. Liver Int 2005;25: 984-6.

6. Tarn AC, Lapworth R. Biochemical analysis of ascitic (peritoneal) fluid: what should we measure? Ann Clin Biochem 2010;47: 397-407.

7. Sabiston DC, Townsend CM. Sabiston textbook of surgery: The biological basis of modern surgical practice. Philadelphia: Elsevier Saunders; 2016.

8. Kasper DL, et al. Medicina Interna de Harrison. 19. ed. Porto Alegre: AMGH, 2017.

9. Krige JEJ , Beckingham IJ. Portal hypertension. Ascites, encephalopathy and other conditions. ACB of diseases of liver, pancreas, and biliary system. BMJ 2001;322: 416-8.

10. Hall JE, Guyton AC. Guyton \& Hall - Tratado de fisiologia médica. 13ª ed. Rio de Janeiro: Elsevier; 2017.

11. Tamsma JT, Keizer HJ, Meinders AE. Pathogenesis of malignant ascites: Starling's law of capillary hemodynamics revisited. Ann Oncol 2001;12: 1353-7.

12. Singhal S, Baikati KK, Jabbour II, Anand S. Management of refractory ascites. Am J Ther 2012;19: 121-32. 
13. Runyon BA, AASLD Practice Guidelines Committee. Management of adult patients with ascites due to cirrhosis: an update. Hepatol 2009;49: 2087.

14. Kumar V, Abbas A, Fausto N. Robbins e Cotran - Patologia: Bases patológicas das doenças. Rio de Janeiro: Elsevier; 2010.

15. Angeli P, Bernardi M, Villanueva C, Francoz C, Mookerjee RP, Trebicka J, et al. EASL Clinical Practice Guidelines for the management of patients with decompensated cirrhosis. Journal of Hepatol 2018;69(2)406-60.

16. Rocco JR. Semiologia Médica. Rio de Janeiro: Elsevier; 2010.

17. Bernardi M, Moreau R, Angeli P, Schnabl B, Arroyo V. Mechanisms of decompensation and organ failure in cirrhosis: From peripheral arterial vasodilation to systemic inflammation hypothesis. J Hepatol 2015;63: 1272-84.

18. Whitebook. Clinical Decision. Procedimentos Médicos. Paracentese [recurso eletrônico]; 2019.

19. Comar SR, et al. Análise citológica do líquido peritoneal. Estud Biol 2010/2011;32/33:76-81/73-9.

20. Runyon BA, Antillon MR, McHutchison JG. Diuresis increases ascitic fluid opsonic activity in patients who survive spontaneous bacterial peritonitis. J Hepatol 1992;14: 249-52.

21. Chinnock BW, Hendey G. Can clear ascitic fluid appearance rule out spontaneous bacterial peritonitis? The American Journal of Emergency Medicine 2007;25(8)934-7.

22. Huang LL, et al. Ascitic Fluid Analysis in the Differential Diagnosis of Ascites: Focus on Cirrhotic Ascites. Journal of Clinical and Translat Hepatol 2014;2(1)58-61.

23. Bernardi M, Caraceni P, Navickis RJ, Wilkes MM. Albumin infusion in patients undergoing largevolume paracentesis: a meta-analysis of randomized trials. Hepatol 2012;55: 1172-81.

24. Moreau R, Valla DC, Durand-Zaleski I, Bronowicki JP, Durand F, Chaput JC, et al. Comparison of outcome in patients with cirrhosis and ascites following treatment with albumin or a synthetic colloid: a randomised controlled pilot trail. Liver Int 2006;26: 46-54. 